\title{
LITHOSTRATIGRAPHY OF LATE WEICHSELIAN TILLS ON THE WEST ESTONIAN ISLANDS
}

\author{
ENE KADASTIK and VOLLI KALM
}

\begin{abstract}
KADASTIK, ENE and KALM, VOLLI 1998. Lithostratigraphy of Late Weichselian tills on the West Estonian Islands. Bulletin of the Geological Society of Finland 70, Parts 1-2, 5-17.

Glacial stratigraphy of the West Estonian Islands comprises three different diamicton units which are correlated event-stratigraphically to the Pandivere and Palivere ice advances of the most recent (Late Weichselian) glaciation and included into the Vorrtsjärve Subformation according to Estonian stratigraphic nomenclature. A large number of till samples (1136) and drillcore sections (2500) were analysed in order to determine the genesis and composition of sediments from which the lithostratigraphical conclusions are derived. The two topmost diamictons are interpreted as genetic varieties of the Palivere Till - waterline melt-out and basal till. The Pandivere Till is the lowermost widespread till layer on the islands, which lies unconformably between the Palivere Till and carbonaceous bedrock. Lacustrine Kõpu Sands separate the Palivere and Pandivere Tills in a few boreholes on the Kõpu and Sorrve Peninsulas. In deeply buried valleys on the Sõrve Peninsula the Pandivere Till is underlain by lacustrine Viieristi Sands and greenish-grey compact till of unknown age. The correlatives of the Palivere and Pandivere Tills in southern Finland, south of Salpausselkä I (SSI), are thought to be the Espoo and Siuntio Tills, respectively.
\end{abstract}

Key words: till, grain size, petrography, mineral composition, chemical composition, lithostratigraphy, correlation, Weichselian, Hiiumaa, Saaremaa, Estonia.

Ene Kadastik, Geological Survey of Estonia, Kadaka 82/84, 12618 Tallinn, Estonia, and Institute of Geology, University of Tartu, Vanemuise 46, 51014 Tartu, Estonia.

Volli Kalm, Institute of Geology, University of Tartu, Vanemuise 46, 51014 Tartu, Estonia

\section{INTRODUCTION}

Earlier research (Raukas 1978, Eltermann 1993, Kadastik 1994, 1995, Kalm \& Kadastik in print) showed that the glacial stratigraphy of the West Estonian Islands (Fig. 1) includes at least three widespread diamicton units, apart from the buried till discovered in a few deep boreholes on the Sõrve Peninsula. The uppermost of the three diamictons was recently classified as a waterline meltout till (Kalm \& Kadastik in print) and the two lower units as basal tills deposited by grounded ice (Raukas et al. 1971, Raukas \& Karukäpp 1978, Raukas 1986, 1992b, 1995). All the three main 


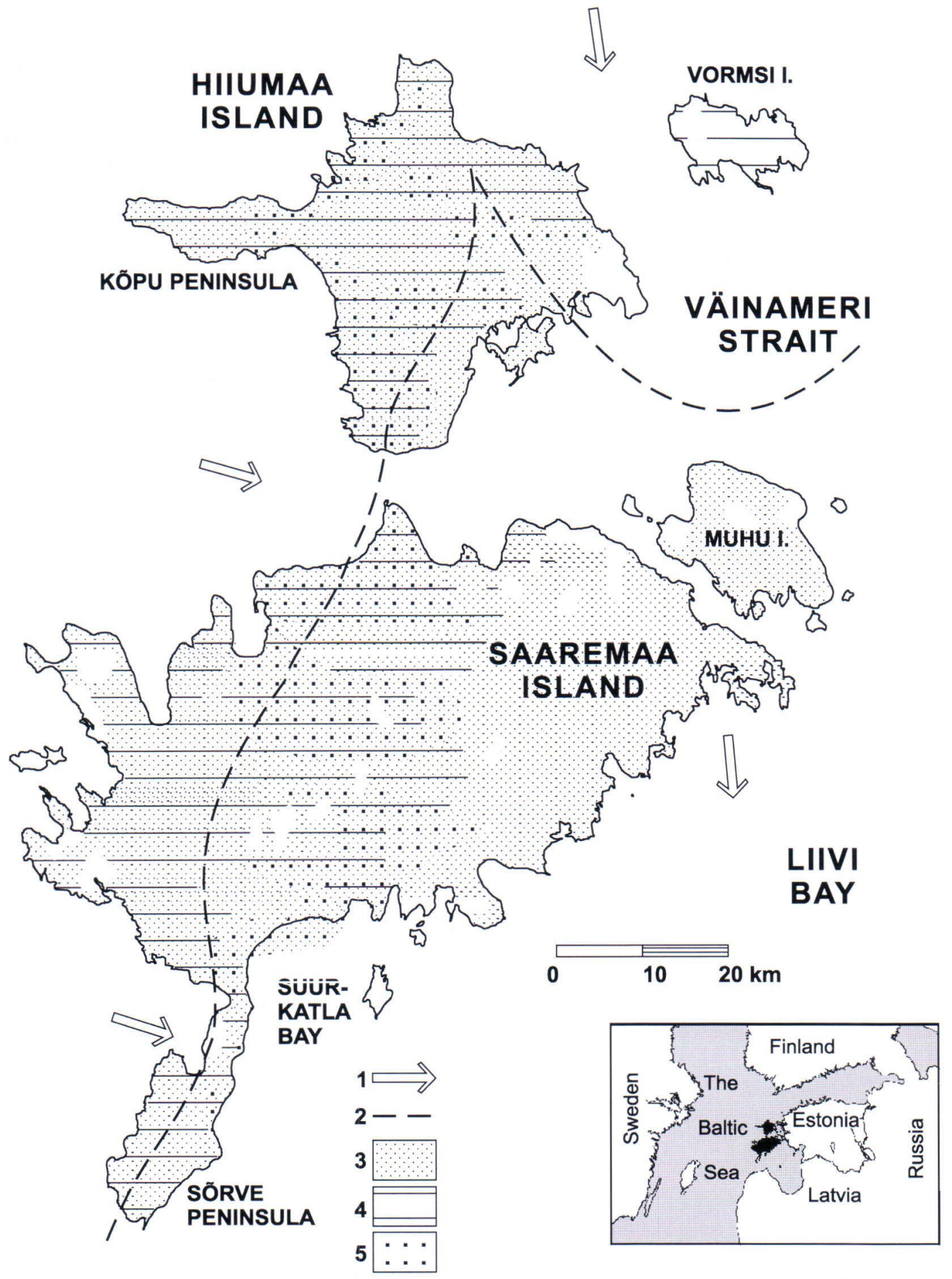

Fig. 1. Map of the study area. 1. Ice flow direction; 2. The maximum extent of the glacier during the Palivere Stade, after A. Raukas (1986, 1992b); 3. The distribution area of the Pandivere Till; 4. The distribution area of the Palivere basal till; 5. The distribution area of the Palivere waterline melt-out till. 


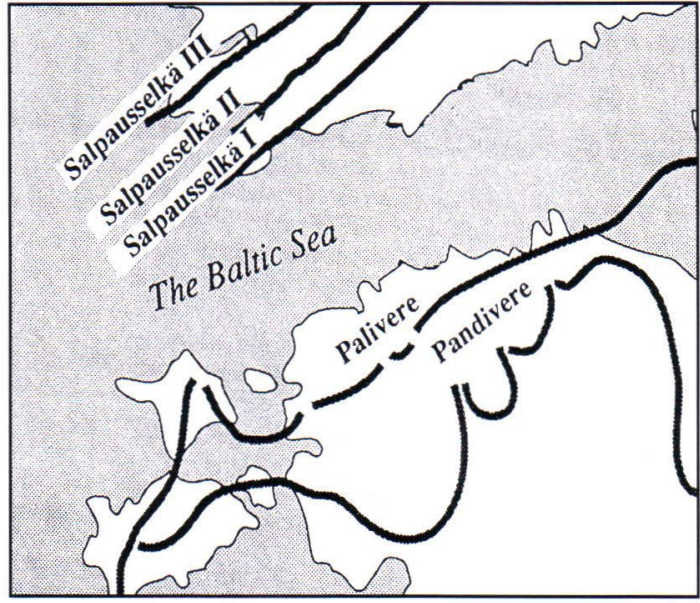

A

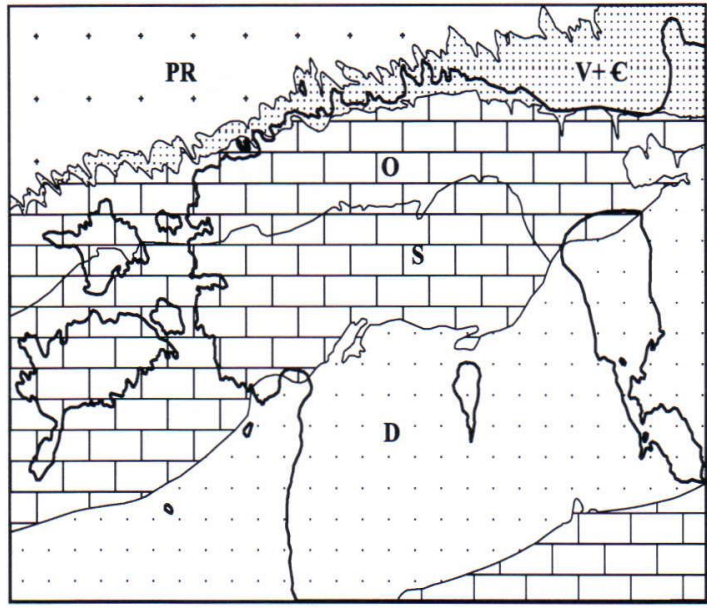

B

Fig. 2. (A) The major endmoraine zones and respective stadials mentioned in the text (according to Salonen \& Glückert 1992). (B) Bedrock of the region. $P R=$ Proterozoic metamorphic rocks and rapakivi granites; $V+C=$ Vendian and Cambrian sandstone, siltstone and claystone; $O=$ Ordovician limestone; $S=$ Silurian dolomite and limestone; $D=$ Devonian sandstone and siltstone.

diamictons are correlated to the Pandivere and Palivere stadials of the most recent (Late Weichselian) glaciation (Raukas et al. 1971, Raukas 1978, Eltermann 1993, Kadastik 1994, 1995, Kalm \& Kadastik in print). These stadials represent the two final glacial advances on the West Estonian Islands and NW Estonia before the Salpausselkä I (SSI; Fig. 2A). According to striae measurements (Männil 1962) and till clast fabric (Raukas et al. 1971), the accumulation of tills in the Pandivere Stade resulted from southerly or southwesterly oriented ice flow, while the flow in the Palivere Stade was mostly southeastwards or even eastwards (Raukas et al. 1971, Raukas \& Karukäpp 1978, Raukas 1986, 1992b, 1995). Based on the morphological evidence of the glacial stadials, Kajak (1996) recently differentiated Palivere, Pandivere, Otepää, Haanja and Misso morphostratigraphical units within the Võrtsjärve Subformation (Late Weichselian glaciation). These units, representing separate ice flow phases, were not supported by lithological data, nor by bio- or chronostratigraphical evidence from the West Estonian Islands. In the absence of bio- or chronostratigraphical data, superposition of differently coloured diamictons and fabrics petrography have been the only methods to distinguish or correlate till units in the area (Fig. 1). However, the usefulness of the application of comprehensive lithological data for stratigraphic purposes has been confirmed in different glaciated regions (e.g. Raukas 1978, Fulton 1984, Kujansuu \& Saarnisto 1990, Ehlers et al. 1995, Walden et al. 1996).

In this article we present the results of grainsize, petrographic, mineralogical and chemical analysis of the above-mentioned glacial deposits and aim at three objectives. Firstly, the areal distribution and general stratigraphic position of different till units in the study area will be characterized and determined. Secondly, we will provide information about and compare the usefulness of various compositional data for purposes of stratigraphic delimitation and correlation of till units. Thirdly, a formal stratigraphical scheme for the Late Weichselian glacial deposits on the West Estonian Islands will be proposed.

\section{STUDY AREA}

The study area covers the West Estonian islands of Hiiumaa, Vormsi, Saaremaa and Muhu (Fig. 1). 
The slightly undulating or hummocky landscape is characteristic of the area. According to the conditions of deposition and pre-Pleistocene relief the structure and thickness of the tills vary a great deal. The thickness is often less than $1 \mathrm{~m}$, but reaches $20-45 \mathrm{~m}$ in places of glacial accumulative landforms or even $70-80 \mathrm{~m}$ in buried valleys. The area was deglaciated between ca 12600 and 11600 BP (Pirrus \& Raukas 1969, Raukas 1986, 1992b, Hang \& Sandgren 1996; see Fig. 2A) and flooded by the waters of the ice-dammed lakes and the Baltic Sea (Raukas 1994). Since the late-glacial times the islands have been emerging from the waters as a result of neotectonic uplift, which is still in progress (Kessel \& Raukas 1979, Miidel \& Vaher 1997).

The underlying bedrock in the study area is limestone and dolomite of Ordovician and Silurian age (Fig. 2B). To the north of the Ordovician limestone a narrow band of Lower Ordovician and Cambrian sandstone, siltstone and claystone outcrop under the Gulf of Finland (see Winterhalter et al. 1981, Raukas \& Hyvärinen 1992). The Ordovician carbonate rocks are mainly represented by various limestones and marlstones (Põlma 1982), whereas the Silurian beds are composed of dolomitic carbonate rocks, marls, claystones and argillites (Jürgenson 1988, Nestor 1997).

\section{MATERIAL AND METHODS}

Most of our data was obtained through geological mapping of Quaternary deposits on a 1:50000 scale between 1986-1994. Because the glacial deposits on the islands are generally covered by late-glacial and Holocene glaciolacustrine, lacustrine or marine deposits, the majority of the samples were taken from drillcores. In total 1136 till samples were subjected to various sedimentological analysis and about 2500 core sections were described and used to draw lithostratigraphical conclusions. Conventional grain-size, mineralogical, petrographical, chemical and X-ray diffraction analysis, outlined in Lewis and McConchie (1994) and in the earlier publications of the authors (Kalm et al. 1992, Kadastik 1994, 1995), were applied to describe the till units.

\section{DISTRIBUTION AND GENERAL DESCRIPTION OF TILL UNITS}

\section{The Palivere tills}

Palivere waterline melt-out till (WMT), the uppermost diamicton in the Pleistocene section on the West Estonian Islands, is a cacao-brown, finegrained clay-rich massive deposit with laminated clayey deposits or brecciated varved clay inclusions and coarse-clastic diamicton lenses, and few gravel- or pebble-size clasts and dropstones. The sporadically distributed WMT overlies the beige Palivere basal till and in some places in east-central Saaremaa the older, greyish Pandivere Till (Kalm \& Kadastik in print). Palaeogeographically, the WMT is restricted to the classical Palivere stadial ice-limit (Raukas 1992b; Fig. 1) and lies mostly at an altitude of between $-15 \mathrm{~m}$ and +10 $\mathrm{m}$ a.s.l. (between $-15 \mathrm{~m}$ and $+5 \mathrm{~m}$ on Saaremaa and between $-15 \mathrm{~m}$ and $+10 \mathrm{~m}$ on Hiiumaa). In the Väinameri area, east of Saaremaa and Hiiumaa (Fig. 1), no WMT was found and the light-grey carbonaceous Pandivere Till is unconformably overlain by late-glacial varved clay (Lutt 1985). At the bottom of Liivi (Riga) Bay no facies similar to the WMT was mapped (Striebins \& Väling 1996), except in the shallow northeasternmost area such as Suur-Katla Bay (Kiipli et al. 1993). In most borehole sections the WMT was identified as massive diamicton with dispersed clasts - coded Dmm (Eyles et al. 1983, Miall 1990). The WMT deposit was interpreted as a subaquatic waterline melt-out till associated with the greyishbeige till of the Palivere Stade (Eltermann 1993, Kadastik 1995, Kalm \& Kadastik in print). In earlier investigations this fine-grained, massive brownish deposit was either not recognized (Raukas et al. 1971, Raukas 1978) or was genetically assigned to glaciolacustrine deposits (Kiipli et al. 1993). Contact between the WMT and the underlying Palivere basal till is typically gradational but in places (such as east-central Saaremaa) the WMT rests unconformably on the Pandivere Till. On Saaremaa the WMT has a gradational boundary with overlying varved clay. In elevated areas, where the varved clay was not deposited or was 
eroded, a sharp contact marked by dropstones or even by a pebbly horizon separates the upper surface of the WMT and marine sands.

Palivere basal till, the second diamicton from the top, is a greyish-beige or brown, coarse-clastic rich, massive lodgement or deformation till, unconformably overlying the grey Pandivere Till or, in some places resting directly on the bedrock (Kadastik 1994, 1995). In some places, for example at Kõpu on Hiiumaa and at Mõntu on the Sõrve Peninsula, interstadial organic-matter bearing lacustrine or marine deposits occur between the Pandivere and Palivere basal tills. Dislocated structures (Plink et al. 1992) and glacial erratic from the Pandivere Till on top of the lacustrine interstadial deposits (Raukas 1978, Eltermann 1993) were described between these two till units. The basal erosional unconformity and deformation of the underlying till indicate the overriding of active ice. The Palivere basal till was mapped only on central and western Saaremaa and sporadically on most of Hiiumaa (Fig. 1). On Saaremaa the Palivere basal till was also mapped outside of the proposed (see Raukas 1986, 1992b) maximum extent of the Palivere glacier. Thickness of this till varies between 2-15 $\mathrm{m}$ on Saaremaa and 2-8 m on Hiiumaa (Kalm \& Kadastik in print). Based on its superposition, this greyish-beige till unit is assigned to the Palivere Stade of glaciation (Raukas et al. 1971, Raukas 1978, Eltermann 1993, Kadastik 1994, 1995) - the stade during which the glacier reached this area for the final time.

\section{The Pandivere Till}

The lowermost widespread diamicton unit is interpreted as basal till, deposited by grounded ice (Raukas et al. 1971, Raukas 1978, 1995, Eltermann 1993, Kadastik 1994, 1995, Kalm \& Kadastik in print). The glacier which deposited this till was considerably enriched with clasts of local bedrock, left glacial striae on the bedrock surface (Männil 1962) and formed a number of subsequently buried endmoraine ridges on Hiiumaa Island (Kadastik 1994). This light-grey carbonateand coarse-clast rich matrix-supported massive diamicton, consisting mostly of subglacial lodgement till, rests unconformably on the carbonaceous bedrock. It is tentatively assigned to the Pandivere Stade (Raukas et al. 1971, Raukas 1978, Plink et al. 1992, Eltermann 1993, Kadastik 1994, 1995), which preceded the Palivere Stade and is dated at ca 12500 BP (Raukas 1992a). The Pandivere Till is mapped on most of Saaremaa, Hiiumaa and smaller islands and, with the exception of the eastern parts of the islands, is overlain by younger tills (Fig. 1). It is $30-40 \mathrm{~m}$ thick in endmoraine ridges and 5-10 $\mathrm{m}$ thick on the plains.

Between the Palivere and Pandivere tills, a massive clayey brown diamiction, similar to waterline melt-out tills, is found in a few boreholes which penetrated buried bedrock-walled valleys on the Sõrve Peninsula. This till is assigned to the end of the Pandivere Stage and, like the Palivere WMT, it has an almost unimodal grain-size distribution with few gravel- or pebble-size clasts in clay-rich matrix. It contains lenses and beds of laminated clayey and silty deposits and is up to 9 $m$ thick at Viieristi.

\section{Pre-Pandivere stadial tills}

A till unit below the Pandivere Till was distinguished in a few boreholes which penetrated buried bedrock-walled valleys. In particular, the pre-Pandivere stadial till unit is described on the Sorrve Peninsula where the grey Pandivere basal till is underlain by a slightly indurated, compact greenish-grey diamicton. Based on this core section, Raukas (1978) presumed that Middle-Pleistocene deposits might be present in the area. However, the stratigraphic position and the age of the greenish-grey till is not clear at present. In boreholes at Mõntu and Viieristi on the Sõrve Peninsula, a layer of lacustrine and fluvial silty sand (Viieristi Sands) is present between the Pandivere Till and the greenish-grey till below. It is unknown whether the greenish-grey diamicton below the lacustrine sand belongs to the earlier stages of the Late Weichselian glaciation or to the Early Weichselian or even to older glaciations. 


\section{LITHOLOGY OF THE TILLS}

A summary of laboratory analyses of the major lithological properties is shown in Table 1. Grainsize analysis proves that the texture of the tills differs significantly. The Pandivere Till has a polymodal grain-size distribution. Figure 3 shows two clear distribution maxima (pebbles and fine sand/coarse silt) with some medium sand and fine gravel maxima. The Palivere basal till has a trimodal grain-size distribution with significant pebble, fine gravel and fine sand fractions. The
WMT has an almost unimodal particle distribution. The particle size data demonstrate that the less the glacier and, respectively, the deposited till had contact with the bedrock below, the more uniform it is in grain-size distribution. The WMT has the highest clay content and, consequently, the lowest mean grain size (Table 1). Also the better sorting, relative to the two lodgement tills below, is characteristic of the WMT. The grain-size ternary diagram shows some overlapping, but still different fields of the three till units (Fig. 4). Compared to the two lodgement tills, the WMT has the least
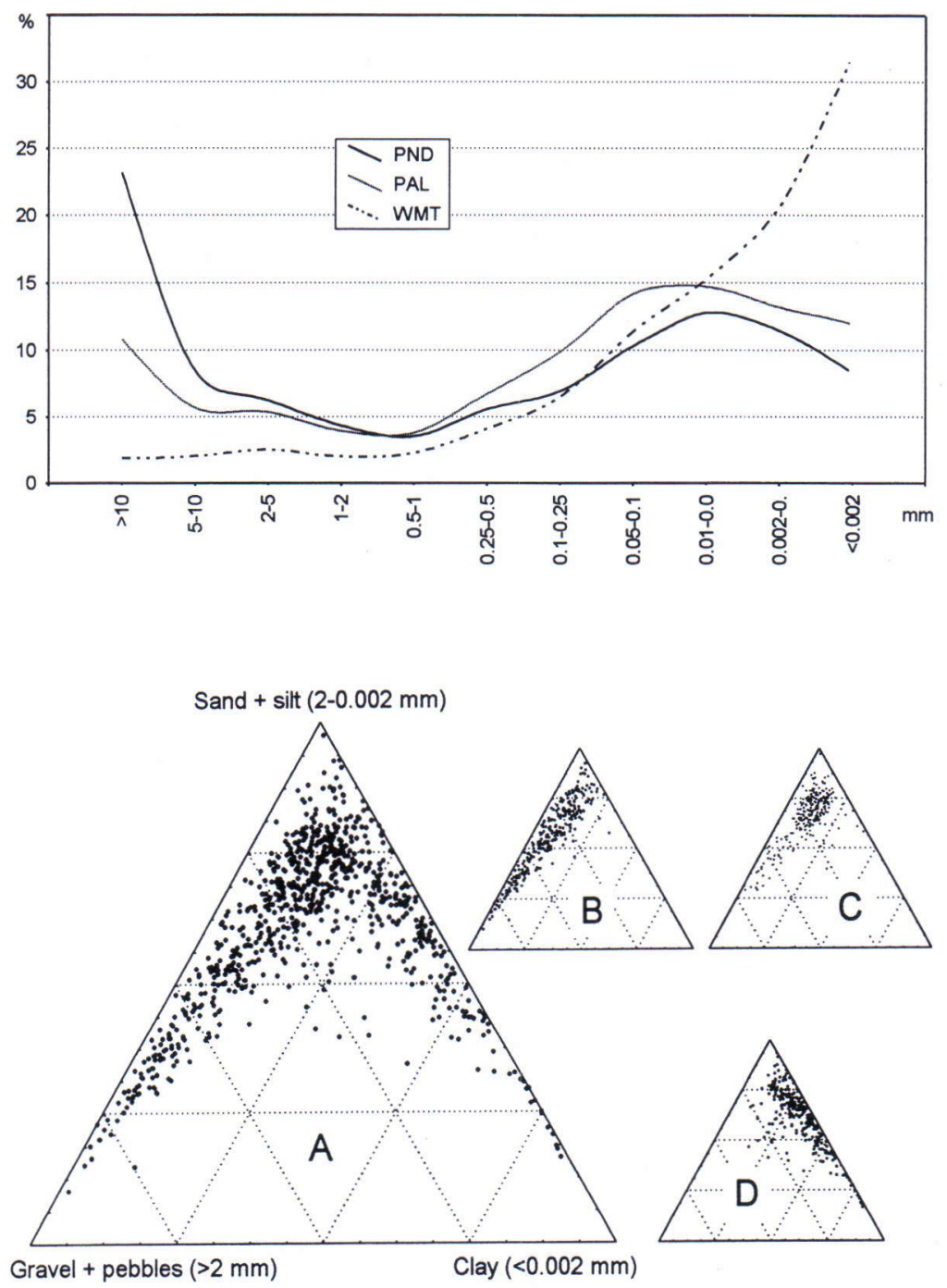

Fig. 3. Distribution curves of grain-size data. $P N D=$ Pandivere Till; $P A L=$ Palivere basal till; $W M T=$ Palivere waterline melt-out till.
Fig. 4. Triangular diagram showing the grain size of the tills studied. A. All analysed samples $(n=797)$; B. Pandivere Till $(n=284) ; C$. Palivere basal till $(n=248) ; D$. Palivere $W M T(n=265)$. 
Table 1. Data on grain-size, petrographic, mineralogical and chemical composition of the studied tills.

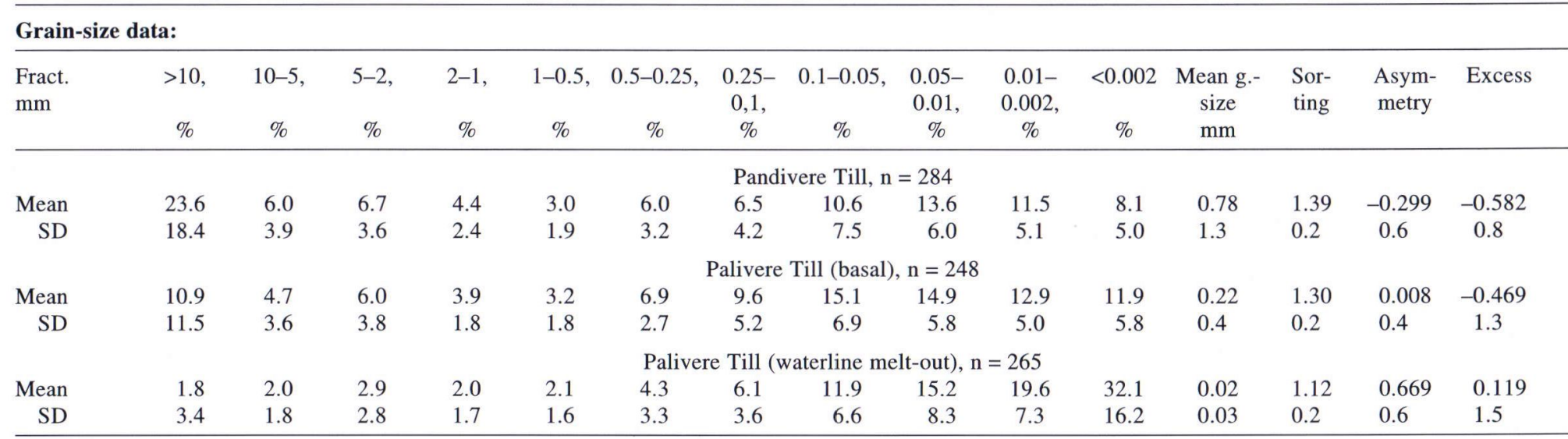

\section{Petrography of coarse fractions:}

\begin{tabular}{|c|c|c|c|c|c|c|c|c|c|c|c|c|c|c|c|}
\hline \multirow[b]{2}{*}{ Fract.: } & \multicolumn{4}{|c|}{ Limestones, \% (L) } & \multicolumn{4}{|c|}{ Dolomites, \% (D) } & \multicolumn{4}{|c|}{ Igneous + Metamorphic, \% (I+M) } & \multicolumn{3}{|c|}{$\mathrm{L}+\mathrm{D} / \mathrm{I}+\mathrm{M}$} \\
\hline & $>40$ & $40-20$ & $20-10$ & $10-5$ & $>40$ & $40-20$ & $20-10$ & $10-5$ & $>40$ & $40-20$ & $20-10$ & $10-5$ & $40-20$ & $20-10$ & $10-5$ \\
\hline & \multicolumn{15}{|c|}{ Pandivere Till } \\
\hline $\mathrm{n}$ & 3 & 3 & 2 & 7 & 3 & 3 & 2 & 7 & 3 & 3 & 2 & 7 & 3 & 2 & 7 \\
\hline Mean & 0 & 0 & 32.0 & 77.3 & 92.8 & 86.5 & 62.0 & 19.3 & 7.2 & 13.5 & 12.1 & 3.4 & 6.41 & 7.8 & 28.4 \\
\hline \multirow[t]{2}{*}{ SD } & - & - & 18.6 & 39.8 & 12.4 & 17.5 & 14.6 & 36.3 & 12.4 & 17.5 & 5.4 & 5.5 & 7.6 & 4.2 & 17.4 \\
\hline & \multicolumn{15}{|c|}{ Palivere Till (basal) } \\
\hline $\mathrm{n}$ & 8 & 18 & 24 & 10 & 8 & 18 & 24 & 10 & 8 & 18 & 24 & 10 & 18 & 24 & 10 \\
\hline Mean & 31.3 & 41.6 & 47.2 & 78.8 & 45.8 & 33.5 & 31.7 & 0.1 & 22.9 & 24.9 & 21.0 & 22.8 & 3.02 & 3.76 & 3.74 \\
\hline \multirow[t]{2}{*}{$\mathrm{SD}$} & 45.8 & 32.4 & 20.1 & 31.3 & 47.8 & 31.3 & 13.5 & 0.1 & 35.3 & 25.8 & 13.7 & 20.3 & 2.9 & 4.3 & 7.2 \\
\hline & \multicolumn{15}{|c|}{ Palivere Till (waterline melt-out) } \\
\hline $\mathrm{n}$ & - & 2 & 7 & 14 & - & 2 & 7 & 14 & - & 2 & 7 & 19 & 2 & 7 & 19 \\
\hline Mean & - & 25.0 & 31.4 & 65.9 & - & 41.7 & 8.3 & 2.3 & - & 33.4 & 37.1 & 29.1 & 1.99 & 1.07 & 2.34 \\
\hline SD & - & 35.4 & 22.8 & 24.7 & - & 11.1 & 10.8 & 6.8 & - & 47.3 & 31.4 & 21.3 & 3.2 & 2.7 & 6.8 \\
\hline
\end{tabular}


Table 1 continued

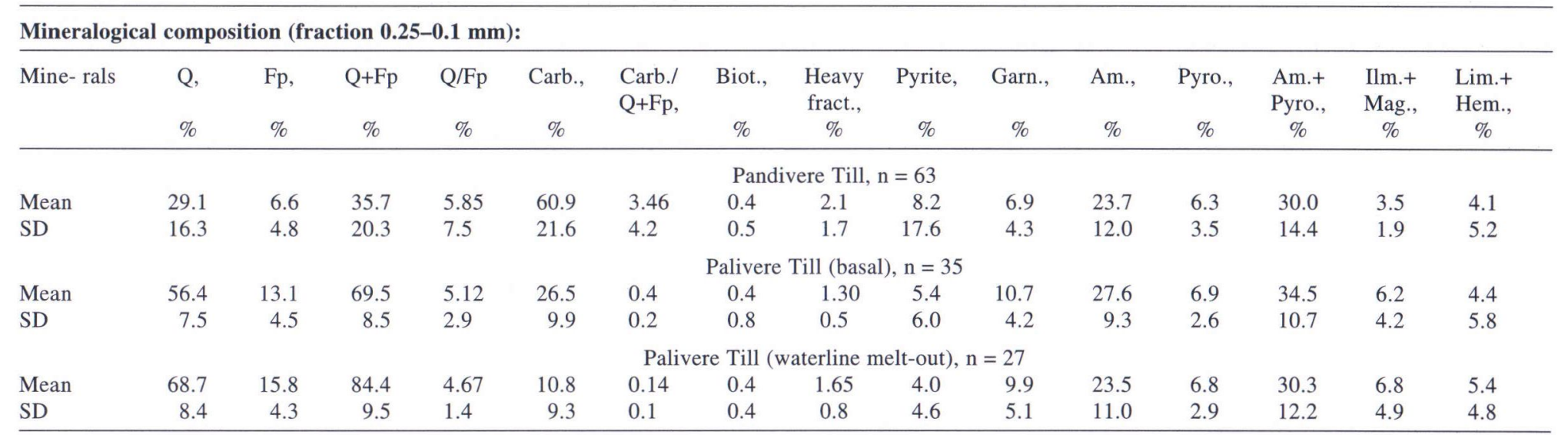

Chemical composition ( $\%$ in $<1 \mathrm{~mm}$ fraction):

\begin{tabular}{|c|c|c|c|c|c|c|c|c|c|c|c|c|c|}
\hline Oxide: & $\mathrm{SiO}_{2}$ & $\mathrm{Al}_{2} \mathrm{O}_{3}$ & $\mathrm{Fe}_{2} \mathrm{O}_{3}$ & $\mathrm{FeO}$ & $\mathrm{K}_{2} \mathrm{O}$ & $\mathrm{CaO}$ & $\mathrm{MgO}$ & $\mathrm{NaO}$ & $\mathrm{CO}_{2}$ & $\mathrm{TiO}_{2}$ & $\mathrm{MnO}_{3}$ & $\mathrm{SiO}_{2} / \mathrm{Al}_{2} \mathrm{O}_{3}$ & $\mathrm{SiO}_{2}+\mathrm{Al}_{2} \mathrm{O}_{3} / \mathrm{CaO}+\mathrm{MgO}$ \\
\hline & \multicolumn{13}{|c|}{ Pandivere Till, $\mathrm{n}=57$} \\
\hline Mean & 34.72 & 5.05 & 1.44 & 0.76 & 1.95 & 20.00 & 8.82 & 0.4 & 25.09 & 0.2 & 0.04 & 6.87 & 1.38 \\
\hline SD & 15.1 & 1.9 & 0.5 & 0.4 & 0.6 & 4.7 & 5.3 & 0.3 & 8.8 & 0.1 & 0.04 & 3.7 & 0.7 \\
\hline \multicolumn{14}{|c|}{ Palivere Till (basal), $\mathrm{n}=40$} \\
\hline Mean & 51.39 & 7.40 & 1.79 & 0.95 & 2.62 & 15.13 & 3.22 & - & 11.66 & - & - & 6.94 & 3.20 \\
\hline SD & 8.0 & 2.1 & 0.9 & 0.5 & 0.7 & 4.8 & 1.4 & - & 7.0 & - & - & 3.1 & 1.2 \\
\hline \multicolumn{14}{|c|}{ Palivere Till (waterline melt-out), $\mathrm{n}=9$} \\
\hline Mean & 53.3 & 14.12 & 3.74 & 2.22 & 3.87 & 7.39 & 2.70 & 1.01 & 5.35 & 0.57 & 0.05 & 3.77 & 6.68 \\
\hline SD & 7.4 & 4.1 & 1.4 & 1.3 & 0.7 & 6.6 & 0.7 & 0.2 & 2.8 & 0.2 & 0.03 & 2.4 & 2.3 \\
\hline
\end{tabular}

$\mathrm{n}=$ number of analysed samples; $\mathrm{SD}=$ standard deviation; Minerals: $\mathrm{Q}=$ Quartz; Fp = Feldspars; Carb. = carbonate minerals; Biot. = Biotite; Heavy fract. = minerals separated by bromoform with a density of $>2.89 \mathrm{~g} / \mathrm{cm}^{3}$; Garn. = garnet; Am. = Amphibole; Pyro. = Pyroxene; Ilm. = Ilmenite; Mag. = Magnetite; Lim. = Limonite; Hem. $=$ Hematite; $-=$ data not available. 
variation in gravel + pebbles fraction and more variable sand + silt and clay content (Fig. 4, Table 1).

Coarse-clastics petrographic composition indicates a similar source material for the WMT and the Palivere basal till. The two Palivere diamictons contain fewer clasts from local carbonaceous bedrock and significantly higher amounts of igneous and metamorphic rocks than the Pandivere Till (Table 1). The deposits of the Palivere stadial, in contrast to the Pandivere deposits, contain rapakivis from southwestern Finland, granites and rapakivis from the Åland Islands, Baltic red quartz-porphyries from Satakunta, all of which are virtually absent in the areas of Pandivere Till outcrops (Raukas 1978, 1986), i.e. in eastern Saaremaa. Data on mineralogical and chemical composition support the lithological differentiation of the Pandivere and Palivere Tills. For example, the ratio of carbonate minerals (calcite + dolomite) to sum of quartz plus feldspar $(\mathrm{Q}+\mathrm{Fp})$ in the fine sand fraction is about one order of magnitude lower in the Palivere basal till and WMT relative to the Pandivere Till (Table 1). The WMT differs from the other studied tills in having highest contents of quartz and feldspars and lowest contents of carbonates (Table 1).

Among the three tills studied here, the contents of Fe-minerals (ilmenite, magnetite, limonite, hematite) and $\mathrm{Fe}_{2} \mathrm{O}_{3}$ (this in the $<1 \mathrm{~mm}$ fraction) are highest in the WMT (Table 1). This accounts for its cacao-brown colour, compared to the beige Palivere basal till and the light-grey Pandivere Till. Kalm et al. (1992) estimated that the WMT and the Palivere basal till on Saaremaa have 5$10 \%$ higher kaolinite and comparatively less illite than the Pandivere Till.

\section{GENERAL LITHOSTRATIGRAPHY AND POSSIBLE CORRELATIONS}

General stratigraphy, based on the lithology and structure of the tills is shown in Fig. 5. According to the distribution of Pleistocene glacial deposits (Fig. 1), the area comprises three zones with different general till stratigraphies: 1 - western- most Saaremaa with two till units (Pandivere Till and Palivere basal till); 2 - central and western Hiiumaa and central Saaremaa with three till units (Pandivere Till and Palivere Till's basal and WMT types); 3 - eastern Saaremaa, Vormsi and Muhu with one till unit (Pandivere Till).

On the Estonian mainland, the Palivere WMT has not been identified. The Palivere basal till and the Pandivere Till are areally delimited by a morphologically well-developed Palivere endmoraine zone. Figure 1 shows that the Palivere basal till is distributed outside the proposed (see Raukas 1986, 1992b) maximum extent of the Palivere glacier. The composition of pollen in the supramorainic deposits at Kunda, northern Estonia, suggests that the Palivere endmoraine zone became free of ice at the beginning of the Alleröd at the latest (Pirrus \& Raukas 1969, Raukas 1992b). On the Estonian mainland both the Pandivere and Palivere Tills are characterised by their grey colour and high carbonate content in areas of carbonate bedrock, and by bluish-grey carbonate-free till in the depressions of the Gulf of Finland (Raukas 1992b). As on the West Estonian Islands, the Palivere Till contains clasts of granite and rapakivi from SW Finland and Åland, which are absent in the Pandivere Till (Raukas 1986).

South of the Salpausselkä I endmoraine in southern Finland (i.e. between SSI and the Palivere endmoraine) two (Hirvas \& Nenonen 1987, Bouchard et al. 1990, Salonen \& Glückert 1992, Saarnisto \& Salonen 1995) or three (Hirvas et al. 1995) till units are distinguished. Because the superficial bedrock composition in Finland and Estonia are completely different, a strictly lithostratigraphic correlation of till units across the Gulf of Finland is not possible. Formal glacial lithostratigraphy of Bouchard et al. (1990) with two till units south of SSI was later complemented with informal climatostratigraphical units together with a time scale (Salonen \& Glückert 1992). This enables a correlation of lithostratigraphical units in the area between the SSI and Pandivere (Neva) Stade based on preliminary chronological approximations (Table 2). However, it should be remembered that the approximate timing of stadial/interstadial episodes in SW Finland are chronostrati- 


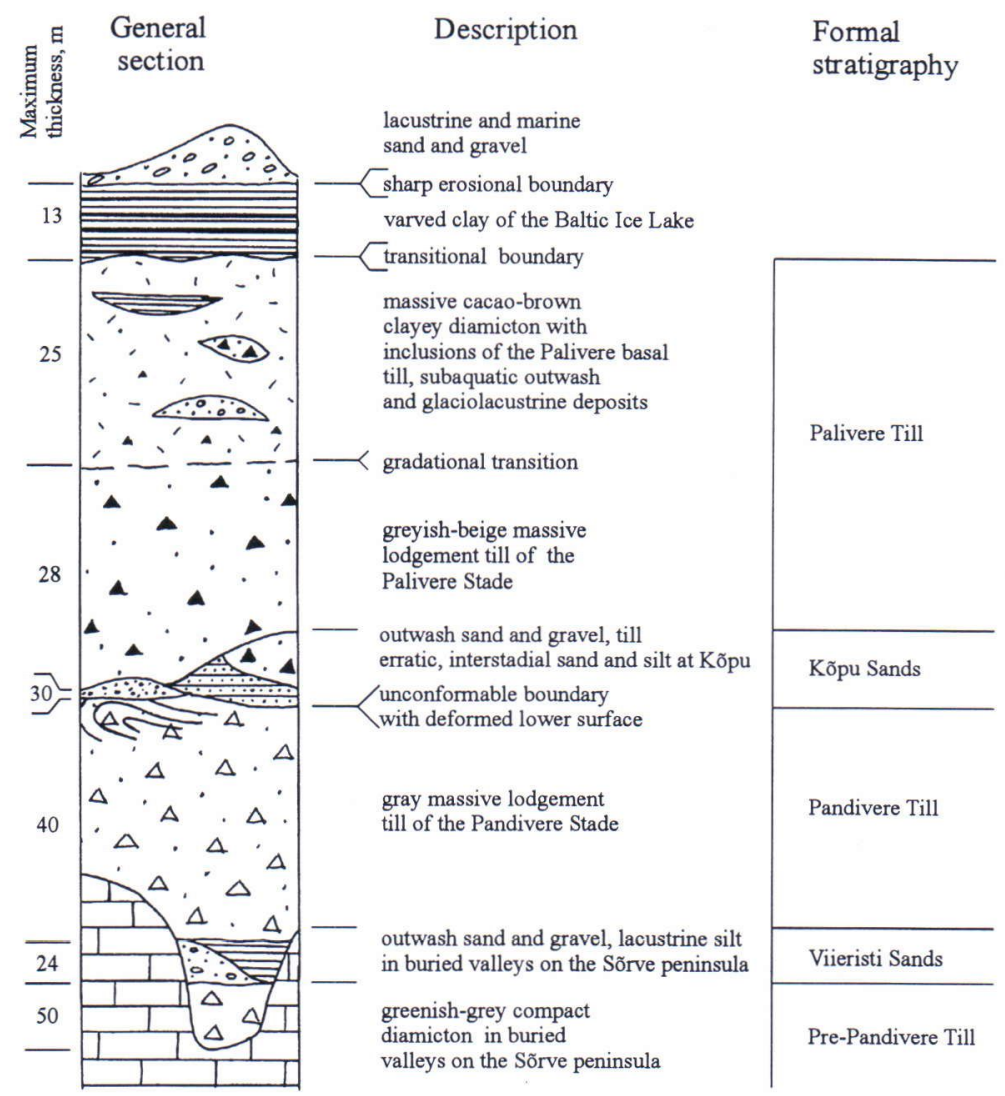

Fig. 5. General lithostratigraphy of glacial deposits on the West Estonian Islands.

graphically not controlled (e.g. Hirvas \& Nenonen 1987, Salonen \& Glückert 1992, Hirvas et al. 1995) and only indirectly determined in NW Estonia (see Pirrus \& Raukas 1969, Raukas 1992a, Hang 1997). Nevertheless, the Espoo Till of Bouchard et al. (1990) and Salonen and Glückert (1992), or till unit 6 of Hirvas et al. (1995) may correlate to the Palivere Till in NW Estonia as both are topmost, youngest and similar age till units in the area between the SSI and Palivere endmoraines (Table 2). This correlation is valid only if it is accepted that the SSI stadial was subsequent to the Palivere stadial with no other ice advances in between.

The Siuntio Till in SW Finland is time-correlative to the Oldest and Older Dryas stadials (Salonen \& Glückert 1992) and thus may be roughly correlated to the Pandivere or older late-glacial tills in Estonia (Table 2). Later, in the Vuosaari section Hirvas et al. (1995) considered the Siuntio Till (unit 4 in Vuosaari) to be of Middle Weichselian age and described an additional till below it, possibly deposited during the Saalian glaciation. As stated above, it is not possible at present to estimate the stratigraphic position of the pre-Pandivere till on the Sorrve Peninsula and to draw correlations to the distinguished till units in SW Finland.

\section{CONCLUSIONS}

General Pleistocene stratigraphy of the West Estonian Islands comprises four tills (the Palivere Till with two sedimentologically different subunits, the Pandivere Till, and as yet unnamed pre- 
Table 2. Formal Pleistocene stratigraphy on the West Estonian Islands and correlation to SW Finland.

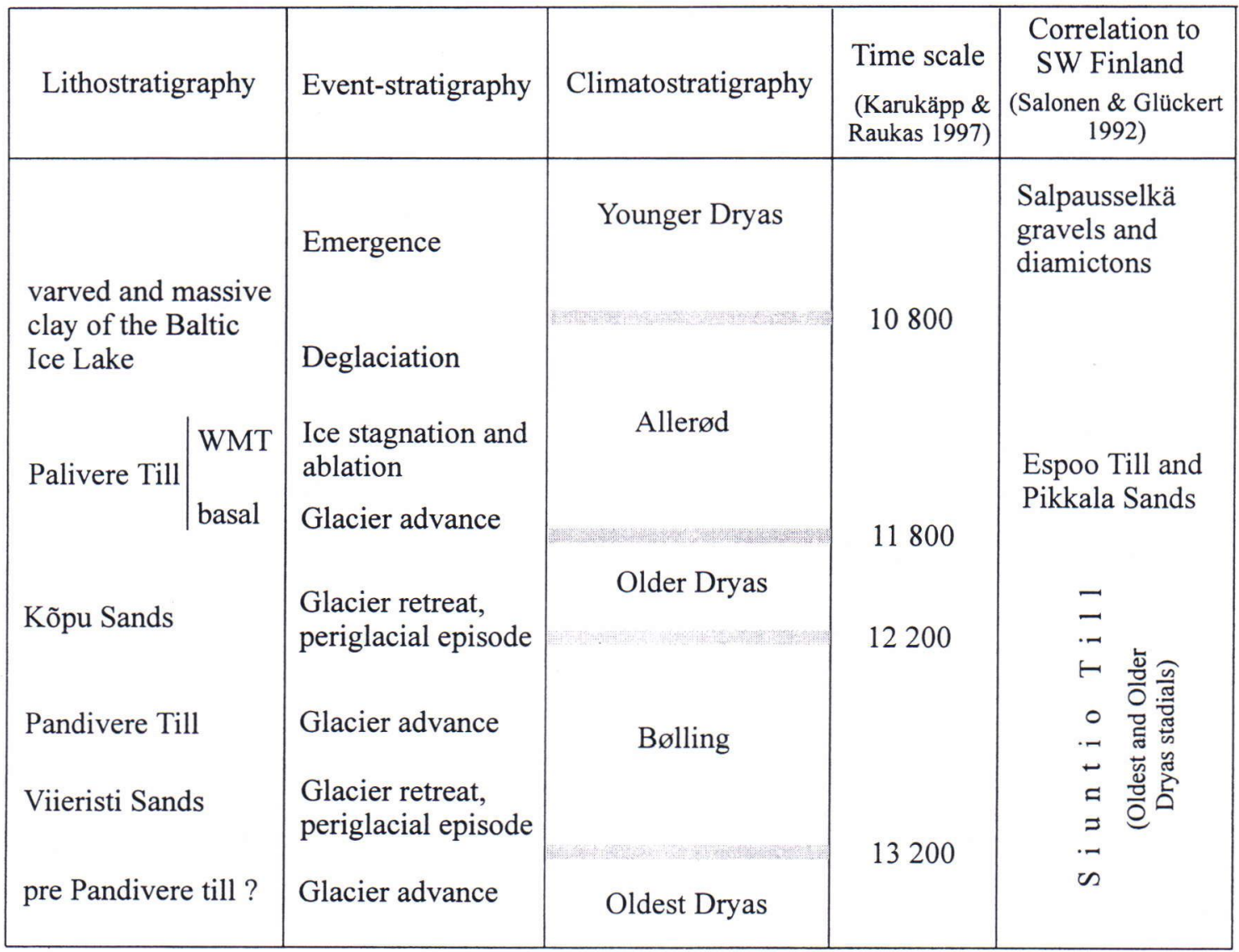

Pandivere Stadial till) and two interstadial/interglacial sand units (the Kõpu and Viieristi Sands). Three areally distributed tills are distinguished by their grain-size distribution and petrographic, mineralogical and chemical composition. Compositional study shows the similarity of source material for the topmost waterline melt-out till (WMT) and the Palivere Stade basal till. Therefore the WMT is interpreted as a different genetic variety but still deposited during the Palivere Stade. The two uppermost diamicton layers comprise the Palivere Till formal unit which is tentatively correlated with the Espoo Till in SW Finland, south of the SSI. In two boreholes on the Kõpu and Sõrve Peninsulas organic-matter containing lacustrine Kõpu Sands occur between the Palivere Till and the underlying Pandivere Till. Data on grain-size distribution and petrographic, mineralogical and chemical composition together provide a reliable lithological differentiation of the Palivere Till from the Pandivere Till. The Pandivere Till is underlain by the interstadial/interglacial Viieristi Sands and the compact greenish-grey till of the pre-Pandivere Stade in buried valleys on the Sõrve Peninsula.

ACKNOWLEDGEMENTS. The authors are deeply indebted to the Geological Survey of Estonia (EGS) for support to Ene Kadastik. Colleagues Kalle Suuroja, Guido Eltermann, Helle Perens and Rein Perens from the EGS are thanked for their help and valuable discussions during the field work. Kalle Kirsimäe (Tartu) is acknowledged for critical comments of the manuscript. The 
research was financed by Estonian Science Foundation grant 1301 and partly supported by Estonian research grant TBGGL0550. We thank Külli Kübar for her help in drafting the illustrations.

\section{REFERENCES}

Bouchard, M.A., Gibbard, P. \& Salonen, V.-P. 1990. Lithostratotypes for Weichselian and pre-Weichselian sediments in southern and western Finland. Bulletin of the Geological Society of Finland 62, 79-95.

Ehlers, J., Kozarski, S. \& Gibbard, P. (eds.) 1995. Glacial Deposits in North-East Europe. Rotterdam: A.A. Balkema. 626 p.

Eltermann, G. 1993. Mandriliustiku hääbumine Lääne-Eesti saartel. Eesti Loodus 5/6, 218- 219.

Eyles, N., Eyles, C.H. \& Miall, A.D. 1983. Lithofacies types and vertical profile models; an alternative approach to the description and environmental interpretation of glacial diamict and diamictite sequences. Sedimentology 30, 393-410.

Fulton, R.J. (ed.) 1984. Quaternary Stratigraphy of Canada - A Canadian Contribution to IGCP Project 24. Geological Survey of Canada, Paper 84-10. 210 p.

Hang, T. 1997. Clay varve chronology in the Eastern Baltic area. Geologiska Föreningens i Stockholm Förhandlingar 119, 295-300.

Hirvas, H. \& Nenonen, K. 1987. The till stratigraphy of Finland. Geological Survey of Finland, Special Paper 3, 49-63.

Hirvas, H., Lintinen, P., Lunkka, J.P., Erikson, B. \& Grönlund, T. 1995. Sedimentation and lithostratigraphy of the Vuosaari multiple till sequence in Helsinki, southern Finland. Bulletin of the Geological Society of Finland 67, 51-64.

Jürgenson, E. 1988. Deposition of the Silurian beds in the Baltic. Tallinn: Valgus. 176 p. (in Russian).

Kadastik, E. 1994. About distribution, formation and lithological composition of tills on Hiiumaa Island, NW Estonia. Bulletin of the Geological Survey of Estonia 4/1, 4-11.

Kadastik, E. 1995. Texture and mineralogical characteristics of Weichselian till on Saaremaa Island. Bulletin of the Geological Survey of Estonia 5/1, 4-11.

Kajak, K. 1996. Quaternary type sections in Estonia (Pleistocene). Geological Survey of Estonia, Report of the Information Department. 20 p.

Kalm, V., Aruväli, J. \& Einmann, A. 1992. Clay mineralogy of surficial fine-grained Quaternary deposits on Saaremaa Island, Western Estonia. Acta et Commentationes Universitatis Tartuensis 956, 95-113.

Kalm, V. \& Kadastik, E. in print. Waterline melt-out till along the Palivere ice-marginal zone on West-Estonian Archipelago, Eastern Baltic Sea. Boreas

Karukäpp \& Raukas, A. 1997. Deglaciation history. In: Raukas, A. \& Teedumäe, A. (eds.) Geology and Min- eral Resources of Estonia. Tallinn: Estonian Academy Publishers, 263-267.

Kessel, H. \& Raukas, A. 1979. The Quaternary History of the Baltic Sea in the Holocene. In: Gudelis, V. \& Königsson, L.-K. (eds.) The Quaternary History of the Baltic. Uppsala: Acta Universitatis Upsaliensis. Symposia Universitatis Upsaliensis, Annum Quingentesimum Celebrantis: 1, 127-146.

Kiipli, T., Liivrand, E., Lutt, J., Pirrus, R. \& Rennel, G. 1993. Pinnakate. In: Lutt, J. \& Raukas, A. (eds.) Eesti selfi geoloogia. Tallinn: Eesti Geoloogia Selts, 76-102. (in Estonian).

Kujansuu, R. \& Saarnisto, M. 1990. Glacial Indicator Tracing. Rotterdam: A.A. Balkema. 252 p.

Lewis, D.W. \& McConchie, D. 1994. Analytical Sedimentology. New York: Chapman \& Hall. 197 p.

Lutt, J. 1985. Bottom deposits of the Väinameri Sea. Tallinn: Estonian Academy of Sciences. 238 p. (in Russian).

Männil, R. 1962. Jääkriimude suunast Eestis. Eesti Geograafia Seltsi aastaraamat 1960/61, 13 - 28. (in Estonian).

Miall, A.D. 1990. Principles of Sedimentary Basin Analysis. Second Edition. New York: Springer-Verlag. 668 p.

Miidel, A. \& Vaher, R. 1997. Neotectonics and recent crustal movements. In: Raukas, A. \& Teedumäe, A. (eds.) Geology and Mineral Resources of Estonia. Tallinn: Estonian Academy Publishers, 177-180.

Nestor, H. 1997. Silurian. In: Raukas, A. \& Teedumäe, A. (eds.) Geology and Mineral Resources of Estonia. Tallinn: Estonian Academy Publishers, 89-106.

Pirrus, R. \& Raukas, A. 1969. On the character and time of the last deglaciation of the territory of Estonia. Voprosy chetvertichnoy geologij 4, 47-57. (in Russian).

Plink, P., Kask, J. \& Eltermann, G. 1992. Formation of Quaternary sediments on Kassari Island. Bulletin of the Geological Survey of Estonia 2/1, 32-37.

Põlma, L. 1982. Comparative Lithology of the Ordovician Carbonate Rocks in the Northern and Middle East Baltic. Tallinn: Valgus. 164 p. (in Russian).

Raukas, A. 1978. Pleistocene Deposits of the Estonian SSR. Tallinn: Valgus. 310 p. (in Russian).

Raukas, A. 1986. Deglaciation of the Gulf of Finland and adjoining areas. Bulletin of the Geological Society of Finland 58, 21-33.

Raukas, A. 1992a. Late- and postglacial geological development and human impact in Estonia. In: Hackens, T., Lang, V. \& Miller, U. (eds.) Estonia: Nature, Man and Cultural Heritage, PACT 37, 23-34.

Raukas, A. 1992b. Ice marginal formations of the Palivere zone in the eastern Baltic. Sveriges Geologiska Undersökning, Ser. Ca 81, 277-284.

Raukas, A. 1994. Annually laminated late-glacial sediments in the Eastern Baltic countries and the evolution of icedammed lakes. In: Hicks, S., Miller, U. \& Saarnisto, M. (eds.) Laminated Sediments. Symposium held at the European University Centre for Cultural Heritage, Ravello, June 1991, 45-55. PACT 41, PACT Belgium, Rixensaart, Belgium. 
Raukas, A. 1995. Properties, origin and stratigraphy of Estonian tills. In: Ehlers, J., Kozarski, S. \& Gibbard, P. (eds.) Glacial Deposits in North-East Europe. Rotterdam: A.A. Balkema, 93-101.

Raukas, A., Rähni, E. \& Miidel, A. 1971. Marginal Glacial Formations in North Estonia. Tallinn: Valgus. 225 p. (in Russian).

Raukas, A. \& Karukäpp, R. 1978. Eesti liustikutekkeliste akumulatiivsete saarkõrgustike ehitus ja kujunemine. In: Raukas, A. (ed.) Eesti NSV saarkõrgustike ja järvenõgude kujunemine. Tallinn: Valgus, 9-28. (in Estonian),

Raukas, A. \& Hyvärinen, H. (eds.) 1992. Geology of the Gulf of Finland. Tallinn: Estonian Academy of Sciences. 422 p.

Saarnisto, M. \& Salonen, V.-P. 1995. Glacial history of Finland. In: Ehlers, J., Kozarski, S. \& Gibbard, P. (eds.) Glacial Deposits in North-East Europe. Rotterdam: A.A. Balkema, 3-10.
Salonen, V.-P. \& Glückert, G. 1992. Late-Weichselian glacial activity and sediments in southwestern Finland. Sveriges Geologiska Undersökning, Ser. Ca 81, 313318.

Striebins, O. \& Väling, P. 1996. Bottom sediments of the Gulf of Riga. Explanatory note to the bottom sediments map, scale 1:200.000. Geological Survey of Latvia \& Geological Survey of Estonia. 53 p.

Walden, J., Smith, J. \& Dackombe, R.V. 1996. A comparison of mineral magnetic, geochemical and mineralogical techniques for compositional studies of glacial diamictons. Boreas 25, 115-130.

Winterhalter, B., Floden, T., Ignatius, H., Åxberg, S. \& Niemistö, L. 1981. Geology of the Baltic Sea. In: Voipio, A. (ed.) The Baltic Sea. Elsevier Oceanography Series 30, 1-121. 